\title{
Use of Clove, Mint and Camphor Essential Oils on Confinement of Clown Anemonefish Amphiprion ocellaris (Cuvier 1830): Anesthetic Effects and Influence on Water Quality
}

\author{
Antonio Ostrensky, Giorgi Dal Pont, Gisela Geraldine Castilho Westphal and Ana Silvia Pedrazzani*
}

Integrated Group for Aquaculture and Environmental Studies (GIA), Department of Animal Science, Federal University of Paraná, Brazil

\begin{abstract}
The aim of this study was to evaluate the anesthetic efficacy of essential oils of clove, mint and camphor to clownfish Amphiprion ocellaris and their effects on water quality in simulated confinement transport conditions. Anesthetic effects of clove, mint and camphor oils were tested at concentrations of $2.5,5.0$ and $7.5 \mu \mathrm{L} \mathrm{L}^{-1} ; 20,25$ and $30 \mu \mathrm{L} \mathrm{L}^{-1}$; and 100, 120 and $140 \mu \mathrm{L} \mathrm{L}^{-1}$, respectively. Confinement periods of $6 \mathrm{~h}, 12 \mathrm{~h}$ and $24 \mathrm{~h}$ were simulated $(\mathrm{n}=8 \mathrm{fish} / \mathrm{time} / \mathrm{concentration})$. Animals were randomly selected and transferred to polyethylene bags $(16 \times 30 \mathrm{~cm}, 5$ fish $\left.\mathrm{L}^{-1}\right)$. Water concentrations of dissolved oxygen (DO), nitrogen in the form of total ammonium $\left(\mathrm{N}-\mathrm{TA}=\mathrm{NH}_{3}+\mathrm{NH}_{4}{ }^{+}\right)$ and non-ionized ammonia $\left(\mathrm{N}-\mathrm{NH}_{3}\right)$ and $\mathrm{pH}$ were measured before closing and after opening the bags. Different

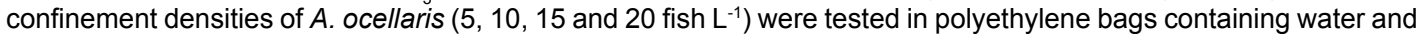
anesthetics essential oils. Concentrations of 5,25 and $120 \mu \mathrm{L} \mathrm{L}^{-1}$ (clove, mint and, camphor oils, respectively) were used during $24 \mathrm{~h}$ of confinement. Water-quality parameters monitored were the same as in the previous experiment, with addition of measuring concentrations of dissolved $\mathrm{CO}_{2}$ in water. The use of mint oil $\left(25 \mu \mathrm{L} \mathrm{L}^{-1}\right.$, maximum density of 10 fish $\left.\mathrm{L}^{-1}\right)$ significantly reduced the concentration of $\mathrm{N}$-TA. At low densities $\left(5\right.$ fish $\left.\mathrm{L}^{-1}\right)$ clove $\left(5 \mu \mathrm{L} \mathrm{L}^{-1}\right)$ and camphor $\left(120 \mu \mathrm{L} \mathrm{L}^{-1}\right)$ oils can also be safely used for confinement of Amphiprion ocellaris for $24 \mathrm{~h}$.
\end{abstract}

Keywords: Immersion anesthesia; Ornamental fish; Plant oils; Reef fish; Transportation

\section{Introduction}

Marine ornamental fish are captured and traded by at least 45 countries, located mainly in tropical and subtropical zones. Emerging countries are responsible for $63 \%$ of the total worldwide reef fish exportation [1]. Two third of this market are dominated by Philippines and Indonesia and the other remaining third is from countries such as the Maldives, Vietnam, Thailand, Sri Lanka, Puerto Rico, Australia, Hawaii and Brazil [2]. United States, European Union and Japan are the biggest importers of ornamental fish [3] and the clown anemonefish Amphiprion ocellaris is the most traded species in terms of number of individuals [4].

Due to the large geographic distances between collection and/or cultivation sites and trader establishment, and the fact that fish must arrive in good conditions at their destination, the productive chain of ornamental fish requires complex logistics for transportation and distribution. The conditions under which the fish are transported directly influence the health and viability of traded animals and, consequently, the economic the operation efficiency [5].

The greatest challenges during the transport of ornamental fish, especially when performed over long distances and at high densities, are to avoid excessive stress, mechanical shocks and deterioration of water quality caused by the elimination of metabolic waste from the fish body, mainly ammonia and carbon dioxide [6-8]. Because ornamental fish are packed in small volumes of water under transport conditions, organic wastes can be accumulated and reach internal toxic concentrations [9].

Sedation is one option used to minimize stress and possible injuries caused by the agitated state of fish during transport [10-12]. Anesthesia reduces metabolic rates and consequently decreases the uptake of oxygen and excretion of metabolic products into water throughout the transport period [13]. Selection of products to be used during transport often depends on factors such as availability, cost-effectiveness, facility of use and safety of handlers [14]. These factors make some essential oils potentially suitable for anesthesia of fish during confinement conditions of transport.

The clove Eugenia caryophyllata essential oil has been studied as a sedative to minimize the effects of transportation on marbled spinefoot Siganus rivulatus [15], largemouth bass Micropterus salmoides [10], mongolian redfin Culter mongolicus [8] and angelfish Pterophyllum scalare [16]. The mint Mentha arvensis and camphor Cinnamomum camphora essential oils have proven anesthetic effects on clownfish Amphiprion ocellaris and can be used during animal laboratory handling [17]. The aim of the present study was to evaluate the anesthetic efficacy of clove, mint and camphor essential oils on clown anemonefish Amphiprion ocellaris and their effects on water quality under confinement conditions similar to transport.

\section{Material and Methods}

Experiments were performed at the Integrated Group of Aquaculture and Environmental Studies (GIA) laboratorial facilities. GIA is located in Curitiba, Paraná, Brazil.

\section{Animal care}

Two hundred juveniles A. ocellaris were acquired from Azul Fish

*Corresponding author: Ana Silvia Pedrazzani, Integrated Group for Aquaculture and Environmental Studies (GIA), Department of Animal Science, Federal University of Paraná, Rua dos Funcionários, 1540 - Curitiba/PR - Brazil, Tel: + 5548 96013347; E-mail: anasilviap@yahoo.com.br

Received September 12, 2016; Accepted November 21, 2016; Published November 23, 2016

Citation: Ostrensky A, Dal Pont G, Castilho-Westphal GG, Pedrazzani AS (2016) Use of Clove, Mint and Camphor Essential Oils on Confinement of Clown Anemonefish Amphiprion ocellaris (Cuvier 1830): Anesthetic Effects and Influence on Water Quality. J Aquac Res Development 7: 457. doi: 10.4172/21559546.1000457

Copyright: (c) 2016 Ostrensky A, et al. This is an open-access article distributed under the terms of the Creative Commons Attribution License, which permits unrestricted use, distribution, and reproduction in any medium, provided the original author and source are credited. 
Citation: Ostrensky A, Dal Pont G, Castilho-Westphal GG, Pedrazzani AS (2016) Use of Clove, Mint and Camphor Essential Oils on Confinement of Clown Anemonefish Amphiprion ocellaris (Cuvier 1830): Anesthetic Effects and Influence on Water Quality. J Aquac Res Development 7 : 457. doi: 10.4172/2155-9546.1000457

$\operatorname{Farm}^{\mathrm{TM}}$ (São Paulo, Brazil). Fish $(\mathrm{Wt}=0.47 \pm 0.42 \mathrm{~g} ; \mathrm{Lt}=2.75 \pm 0.39 \mathrm{~cm})$ were transported at a density of $10 \mathrm{fish}^{-1}$, in plastic bags containing water and oxygen (1:2 ratio). For transportation, plastic bags were placed into isothermal boxes. The trip (from packing until arrive) lasted 7 hours. In laboratory, animals underwent gradual acclimation of temperature, $\mathrm{pH}$ and salinity for approximately $30 \mathrm{~min}$. Acclimated fish were transferred to three $200 \mathrm{~L}$ glass tanks. Black plastic film was attached to the back of the tanks to reduce external light incidence. A saltwater recirculation system connected to the tanks maintained water quality stable (salinity $=30 \mathrm{~g} \mathrm{~L}^{-1}$, temperature $=24 \pm 0.5^{\circ} \mathrm{C} ; \mathrm{pH}=7.9 \pm$ 0.02 ; nitrogen in the form of total ammonium $\left(\mathrm{N}-\mathrm{TA}=\mathrm{NH}_{3}+\mathrm{NH}_{4}^{+} \leq\right.$ $\left.0.25 \mathrm{mg} \mathrm{L}^{-1}\right)$ and fish were kept in these conditions for 180 days. Partial water changes $(25 \% \mathrm{v} / \mathrm{v})$ were performed weekly. Fish were fed twice daily ad libitum with a commercial diet containing $47.5 \%$ of crude protein (TETRA $^{\mathrm{TM}}$, MELLE, Germany). One hour after feeding leftover food and fecal particles were siphoned.

\section{Anesthetic effect of essential oils to fish and its influence on water quality under confinement conditions}

Three different concentrations of clove $\left(2.5,5.0\right.$ and $\left.7.5 \mu \mathrm{L} \mathrm{L}^{-1}\right)$, mint $\left(20,25\right.$ and $\left.30 \mu \mathrm{L} \mathrm{L}^{-1}\right)$ and camphor $\left(100,120\right.$ and $\left.140 \mu \mathrm{L} \mathrm{L}^{-1}\right)$ essential oils were tested simulating confinement conditions typically used during transport. Confinement periods of $6 \mathrm{~h}, 12 \mathrm{~h}$ and $24 \mathrm{~h}(\mathrm{n}=8$ fish per time/concentration) were tested and concentrations were determined based on a previous study [17] and on a pilot test.

Essential oils were acquired from Ferquima ${ }^{\mathrm{TM}}$ Indústria e Comércio de Óleos Essenciais (São Paulo, Brazil). The essentials oils main compounds, obtained by chromatographic analysis, were: camphor oil= 1.8-cineole (35.5\%), limonene (30.0\%), alpha-pinene (13.0\%) and paracymene $(10.0 \%)$; clove oil $=$ eugenol $(85.0 \%)$ and beta caryophyllene $(13.0 \%)$; mint oil $=1$-menthol $(37.0 \%)$, menthone $(20.25 \%)$, limonene $(6.75 \%)$, isomenthone $(7.48 \%)$, menthyl acetate $(4.60 \%)$, isopulegone ( $1.81 \%)$, pulegone $(1.39 \%)$, carvone $(0.08 \%)$ and cineole $(0.34 \%)$. Stock solutions were prepared by diluting each essential oil in ethanol $100 \%$ (1:10). All results were compared to those obtained from a control group in which the fish were exposed only to clean saltwater.

To simulate confinement conditions comparable to those used for fish transport in Brazilian market, fish were randomly selected from the maintenance tanks and transferred to polyethylene bags $(16 \times 30$ $\mathrm{cm}$ ) at a density of $5 \mathrm{fish} \mathrm{L}^{-1}$. Bags were filled with $400 \mathrm{~mL}$ of saltwater and pure oxygen (1:2 ratio) plus one of the experimental anesthetic concentrations. The containers were sealed with rubber bands and arranged in isothermal boxes (identical to those used to transport ornamental fish), and remained there for one of the tested confinement period.

At the end of the confinement exposure period, the anesthesia stage induced by each essential oil was evaluated. The considered stages of fish anesthesia were: (I) absence of reaction to touch and to visual stimulus; (II) initial loss of balance, characterized by difficulty to maintain normal swimming position; (III) total loss of balance, uncoordinated swimming; (IV) minimal opercula movement, no swimming and $(\mathrm{V})$ medullar collapse and no opercula beating, death. For recovery fish were distributed evenly in a salt-water recirculation system with a $900 \mathrm{~L}$ capacity, divided into 15 storage tanks of $60 \mathrm{~L}$. This system had controlled water quality conditions similar to the maintenance tanks. During recovery, fish were visually monitored for $72 \mathrm{~h}$ in order to identify morality, appearance of body injuries and alterations on feeding behavior.

Physical-chemical water quality parameters were measured in two moments: (1) before the injection of oxygen and closing of the bags (initial values) and (2) after opening the packages (final values). Water samples were immediately tested for the determination of $\mathrm{pH}\left(\mathrm{AZ}^{\mathrm{TM}} 86505\right.$ PHMETER, Taiwan), oxygen concentration and temperature (YSI ${ }^{\mathrm{TM}} 550 \mathrm{~A}$, USA). NA-T concentrations were spectrophotometrically (SPECTRONIC 20 GENESYS $^{\text {TM }}$, England) determined according to the indophenol method [18] The concentration of N-TA and $\mathrm{N}^{-\mathrm{NH}_{3}}$ were calculated according to the formula described by Ostrensky, Marchiori [19].

\section{Effect of fish density on water quality using essential oils for anesthetic purposes}

A second experiment was performed to evaluate the effect of clove, mint and camphor oils on water quality parameters during confinement condition at different densities. Each essential oil was tested in four densities $\left(5,10,15\right.$ and 20 fish $\left.\mathrm{L}^{-1}\right)$. These values were based on pilot experimental results. Experimental procedures consisted in placing five fish in one polyethylene bag (4 replicates/treatment). The total volume of saltwater was reduced to increase the density of fish in the confinement bag. For the densities of 5, 10, 15 and $20 \mathrm{fish} \mathrm{L}^{-1}$ were used $1.000,500,333$ and $250 \mathrm{~mL}$ of clean saltwater, respectively. Based on the results obtained on the previously experiment, one concentration of each anesthetic oil was used in the density test: $5 \mu \mathrm{L} \mathrm{L}^{-1}$ of clove oil, $25 \mu \mathrm{L} \mathrm{L}^{-1}$ of mint oil and $120 \mu \mathrm{L} \mathrm{L}^{-1}$ of camphor oil. Results were compared with a control group (clean saltwater with no addition of anesthetic substances).

The methods used for housing animals in polyethylene bags and determining the physic-chemical parameters of the confinement water were similar to the previous experiment. In this experiment, the concentration of dissolved carbon dioxide $\left(\mathrm{CO}_{2}\right)$ in water was also measured by colorimetric titration using sodium hydroxide and phenolphthalein [20] before (initial) and after (final) $24 \mathrm{~h}$. Initials levels of $\mathrm{DO}, \mathrm{CO}_{2}$, temperature and $\mathrm{pH}$ before the experiment were $5.89 \pm$ $0.34 \mathrm{mg} \mathrm{L}^{-1}, 5.60 \pm 0.49 \mathrm{mg} \mathrm{L}^{-1}, 24.5 \pm 0.40{ }^{\circ} \mathrm{C}$ and $7.9 \pm 0.02$ (mean \pm standard deviation), respectively. Concentrations of N-TA and $\mathrm{N}-\mathrm{NH}_{3}$ remained below detection limit of the method used. Mortality and feeding behavior were also evaluated during the $72 \mathrm{~h}$ immediately following the experiment.

\section{Statistical analysis}

Normality of data was assessed by Shapiro-Wilk test. Differences between tested variables were analyzed through Kruskal-Wallis test $(\mathrm{p}<0.05)$. The results obtained using each anesthetic in different concentrations, confinement times and densities were analyzed separately. Subsequently, the outcomes of different anesthetic treatments were compared in terms of confinement water quality parameters. All analyses were performed using the software Statsoft Statistica ${ }^{\text {Tx }}$ version 10.0 .

\section{Results}

\section{Anesthetic effect and influence of using essential oils on water quality under transport conditions}

No mortally was observed during maintenance period. Initial level of DO, temperature and $\mathrm{pH}$ were $6.0 \pm 0.18 \mathrm{mg} \mathrm{L}^{-1}, 24.5 \pm 0.32^{\circ} \mathrm{C}$ and $7.9 \pm 0.01$, respectively. Concentrations of N-TA and $\mathrm{N}-\mathrm{NH}_{3}$ remained undetectable. Fish exposed to the lowest concentration of clove oil (2.5 $\left.\mu \mathrm{L}^{-1}\right)$ showed no characteristic behavioral signs of anesthesia. Other two tested concentrations $\left(5\right.$ and $\left.7.5 \mu \mathrm{L} \mathrm{L}^{-1}\right)$ induced evidences of anesthetic stage III and IV after $6 \mathrm{~h}$ of exposure and stages II and III after $12 \mathrm{~h}$. All mint oil concentrations tested have induced anesthesia. At $6 \mathrm{~h}$ of 
Citation: Ostrensky A, Dal Pont G, Castilho-Westphal GG, Pedrazzani AS (2016) Use of Clove, Mint and Camphor Essential Oils on Confinement of Clown Anemonefish Amphiprion ocellaris (Cuvier 1830): Anesthetic Effects and Influence on Water Quality. J Aquac Res Development 7: 457. doi: 10.4172/2155-9546.1000457

Page 3 of 7

\begin{tabular}{|c|c|c|c|c|c|}
\hline \multirow{2}{*}{ Treatment } & \multirow{2}{*}{ Concentration $\left(\mu L^{-1}\right)$} & \multicolumn{3}{|c|}{ Stage } & \multirow{2}{*}{ Mortality (\%) } \\
\hline & & $6 \mathrm{~h}$ & $12 \mathrm{~h}$ & $24 \mathrm{~h}$ & \\
\hline Control & 0 & - & - & - & 0 \\
\hline \multirow{3}{*}{ Clove } & 2.5 & - & - & - & 0 \\
\hline & 5.0 & III & II & - & 0 \\
\hline & 7.5 & IV & III & - & $50.0^{\mathrm{a}}$ \\
\hline \multirow{3}{*}{ Mint } & 20 & II & - & - & 0 \\
\hline & 25 & III & II & - & 0 \\
\hline & 30 & IV & IV & - & $25.0^{\mathrm{a}}$ \\
\hline \multirow{3}{*}{ Camphor } & 100 & II & - & - & 0 \\
\hline & 120 & IV & II & II & 0 \\
\hline & 140 & IV & IV & II & $37.5^{\star}$ \\
\hline
\end{tabular}

"Note: All deaths occurred on the $24 \mathrm{~h}$ of confinement treatments.

Table 1: Anesthetic stage and mortality (\%) observed after Amphiprion ocellaris confinement for different periods of using different concentrations of clove, mint and camphor oils as anesthetic substances in addition to the control treatment (clean saltwater).
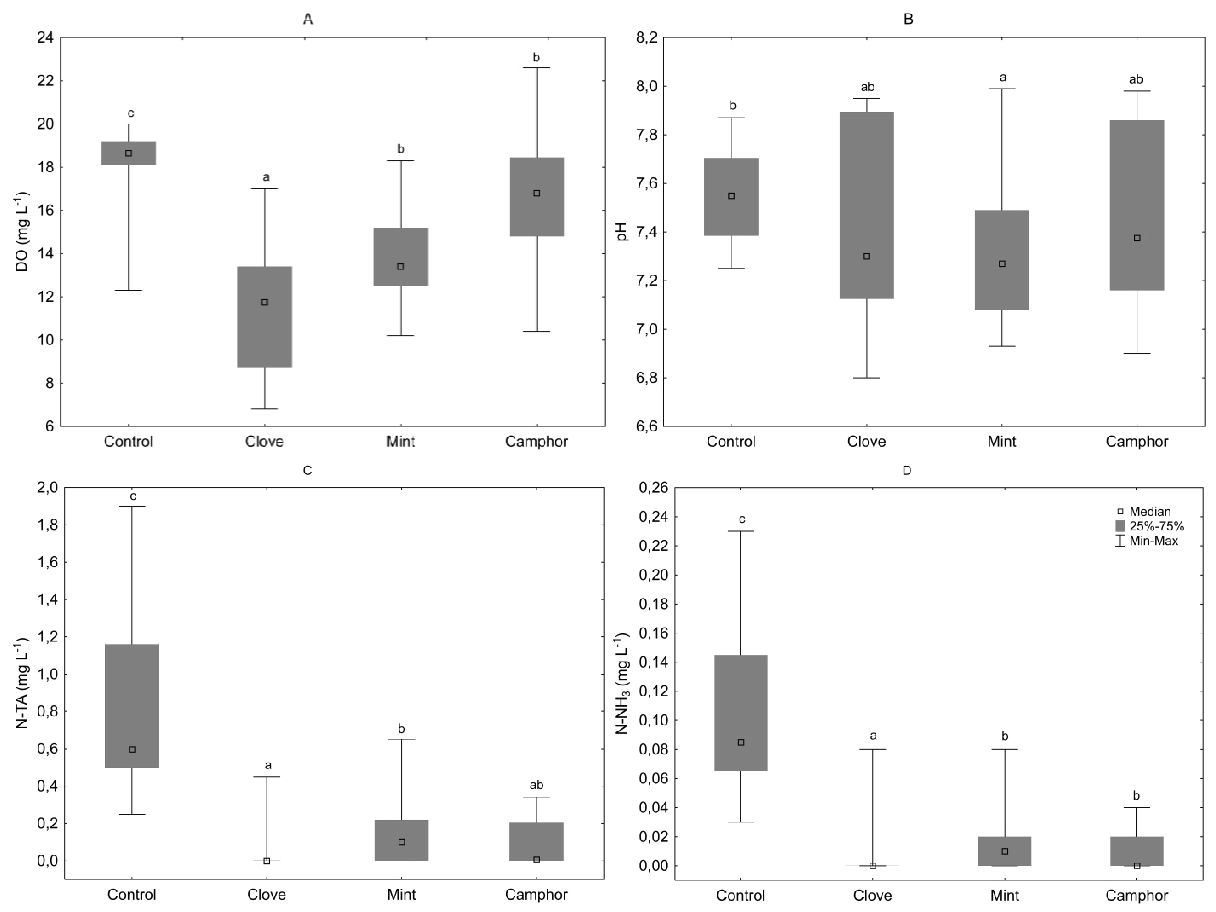

Figure 1: Measured values of dissolved oxygen (DO), $\mathrm{pH}$, nitrogen in the form of total ammonium $\left(\mathrm{N}-\mathrm{TA}^{-} \mathrm{NH}_{3}+\mathrm{NH}_{4}{ }^{+}\right)$and non-ionized ammonia $\left(\mathrm{N}-\mathrm{NH}_{3}\right)$ in confinement water using clove, mint, camphor oils as anesthetic and a control treatment to Amphiprion ocellaris. Letters indicate significant differences among treatments ( $\mathrm{p}<0.05)$

exposure, stages II, III and IV were observed in treatments 20, 25 and $30 \mu \mathrm{L} \mathrm{L}^{-1}$, respectively. Fish exposed to the two highest concentrations of this same oil showed signs of anesthesia stage II and IV after $12 \mathrm{~h}$, respectively. The lowest concentration of camphor oil $\left(100 \mu \mathrm{L} \mathrm{L}^{-1}\right)$ was sufficient to induce only stage II at $6 \mathrm{~h}$, while 120 and $140 \mu \mathrm{L} \mathrm{L}^{-1}$ induced stage IV at $6 \mathrm{~h}$ and led to stages II and IV, respectively, after $12 \mathrm{~h}$ (Table 1). No behavioral signs of anesthesia were identified in fish $24 \mathrm{~h}$ after starting the experiment at any tested concentration of clove and mint oils. In contrast, the two highest concentrations of camphor oil were sufficient to keep the animals at anesthetic stage II until the end of this period. Moreover, the highest concentrations tested for all oils caused the death of some animals, reaching $50 \%$ with clove oil. The deaths always occurred between $12 \mathrm{~h}$ and $24 \mathrm{~h}$ after initial exposure to anesthetic.

There were no significant effects on the water-quality parameters when comparing different concentration of the same oil and period. However, there were significant differences in all water-quality parameters among the different periods of confinement. For all treatments, there was a declining trend in the DO concentration in water relative to the control. This same pattern is evident when comparing $\mathrm{pH}$ values, through water acidification occurred over the $24 \mathrm{~h}$ of experimentation in all treatments. At the beginning of the experiment, there were no detectable ammonia concentrations in the control. During the experiment, ammonia levels reached up to $1.90 \mathrm{mg} \mathrm{L}^{-1}$ of N-TA and $0.23 \mathrm{mg} \mathrm{L}^{-1}$ of N-NH in this same treatment. In treatments with camphor oil, there was an increase in the concentrations of N-TA and N-NH $\mathrm{NH}_{3}$ after $12 \mathrm{~h}$. However, these values remained visually unchanged into $24 \mathrm{~h}$. In contrast, for the treatments with clove and mint oils, except at a concentration of $7.5 \mu \mathrm{L} \mathrm{L}^{-1}$, which remained stable, there was an increase in the concentrations of N-TA and $\mathrm{N}-\mathrm{NH}_{3}$ at $6 \mathrm{~h}$ and a decreasing trend between $12 \mathrm{~h}$ and $24 \mathrm{~h}$, when concentrations were near to zero.

\section{Pooled analysis of the effects of each anesthetic on water quality}

Water quality parameters (DO, $\mathrm{pH}, \mathrm{N}-\mathrm{TA}$ and $\mathrm{N}-\mathrm{NH}_{3}$ ) did not 
Citation: Ostrensky A, Dal Pont G, Castilho-Westphal GG, Pedrazzani AS (2016) Use of Clove, Mint and Camphor Essential Oils on Confinement of Clown Anemonefish Amphiprion ocellaris (Cuvier 1830): Anesthetic Effects and Influence on Water Quality. J Aquac Res Development 7: 457. doi: 10.4172/2155-9546.1000457

Page 4 of 7

\begin{tabular}{|c|c|c|c|c|c|c|c|}
\hline \multirow{2}{*}{ Treatment } & \multirow{2}{*}{$\begin{array}{c}\text { Concentration } \\
\left(\mu L L^{-1}\right)\end{array}$} & \multicolumn{3}{|c|}{$\mathrm{DO}\left(\mathrm{mg} \mathrm{L}^{-1}\right)$} & \multicolumn{3}{|c|}{$\mathrm{pH}$} \\
\hline & & $6 \mathrm{~h}$ & $12 \mathrm{~h}$ & $24 \mathrm{~h}$ & $6 \mathrm{~h}$ & $12 \mathrm{~h}$ & $24 \mathrm{~h}$ \\
\hline Control & 0 & $17.7(12.3-18.9)^{\mathrm{a}}$ & $18.8(18.4-20.0)^{\mathrm{b}}$ & $\begin{array}{c}19.2(18.3- \\
20.0)^{\mathrm{b}}\end{array}$ & $7.83(7.45-7.87)^{\mathrm{a}}$ & $7.60(7.50-7.60)^{\mathrm{a}}$ & $7.34(731-7.45)^{b}$ \\
\hline \multirow{3}{*}{ Clove oil } & 2.5 & $14.3(13.7-16.6)$ & $13.4(12.3-14.0)$ & $13.8(11.5-14.0)$ & $7.92(7.91-7.92)^{a}$ & $7.37(7.247 .63)^{a b}$ & $7.18(7.08-7.24)^{b}$ \\
\hline & 5.0 & $12.4(6.8-12.8)^{a}$ & $11.7(6.9-8.4)^{\mathrm{a}}$ & $7.4(6.9-8.4)^{b}$ & $7.91(7.89-7.93)^{a}$ & $7.28(7.26-7.30)^{\mathrm{ab}}$ & $6.86(6.83-6.88)^{\mathrm{b}}$ \\
\hline & 7.5 & $10.5(9.1-11.3)^{\mathrm{a}}$ & $11.7(10.9-12.2)^{a}$ & $7.3(7.2-7.8)^{b}$ & $7.91(7.86-7.94)^{\mathrm{a}}$ & $7.32(7.28-7.41)^{\mathrm{ab}}$ & $6.87(6.80-6.92)^{b}$ \\
\hline \multirow{3}{*}{ Mint oil } & 20.0 & $16.3(15.8-16.8)^{a}$ & $13.1(14.5-18.7)^{\mathrm{b}}$ & $\begin{array}{c}15.1(14.1- \\
16.9)^{\mathrm{a}}\end{array}$ & $7.90(7.87-7.99)^{\mathrm{a}}$ & $7.13(7.07-7.21)^{\mathrm{b}}$ & $7.28(7.27-7.32)^{a t}$ \\
\hline & 25.0 & $15.2(13.4-16.2)^{a}$ & $12.1(10.4-19.6)^{\mathrm{a}}$ & $11.7(11.2-12.9)^{b}$ & $7.93(7.81-7.99)^{a}$ & $7.24(7.08-7.34)^{\mathrm{ab}}$ & $6.97(6.98-7.00)^{b}$ \\
\hline & 30.0 & $14.2(13.4-15.2)^{\mathrm{a}}$ & $13.6(12.9-15.5)^{\mathrm{a}}$ & $\begin{array}{c}11.4(10.2- \\
12.2)^{\mathrm{b}}\end{array}$ & $7.43(7.38-7.49)^{\mathrm{a}}$ & $7.21(7.17-7.30)^{\mathrm{ab}}$ & $6.99(6.98-7.00)^{b}$ \\
\hline \multirow{3}{*}{ Camphor oil } & 100.0 & $17.6(16.6-19.3)^{\mathrm{a}}$ & $16.8(14.5-18.7)^{\mathrm{ab}}$ & $\begin{array}{c}14.2(10.5- \\
17.2)^{\mathrm{b}}\end{array}$ & $7.81(7.53-7.87)^{a}$ & $7.40(7.34-7.43)^{\mathrm{ab}}$ & $7.01(6.90-7.15)^{\mathrm{b}}$ \\
\hline & 120.0 & $18.5(17.6-22.6)^{a}$ & $17.0(10.4-19.6)^{\mathrm{ab}}$ & $\begin{array}{c}14.3(13.6- \\
17.4)^{\mathrm{b}}\end{array}$ & $7.89(7.87-7.89)^{a}$ & $7.39(7.37-7.41)^{\mathrm{ab}}$ & $7.11(7.07-7.16)^{b}$ \\
\hline & 140.0 & $18.5(18.0-19.1)^{\mathrm{a}}$ & $14.90(12.9-15.5)^{\mathrm{b}}$ & $\begin{array}{c}16.0(15.1- \\
17.3)^{\mathrm{ab}}\end{array}$ & $7.88(7.87-7.98)^{\mathrm{a}}$ & $7.21(7.18-7.33)^{\mathrm{b}}$ & $7.17(7.11-7.20)^{\mathrm{b}}$ \\
\hline
\end{tabular}

Note Letters indicate statistical difference $(p<0.05)$ among tested confinement periods (horizontal). There were no statistical differences $(p>0.05)$ among treatments in the same confinement period (vertical) $(p>0.05)$

Table 2: Median ( $\min$ and $\max$ ) values of dissolved oxygen (DO) and pH in saltwater after different periods of Amphiprion ocellaris confinement using the clove, mint and camphor oils as anesthetic substances and a control treatment.

\begin{tabular}{|c|c|c|c|c|c|c|c|}
\hline \multirow{2}{*}{ Treatment } & \multirow{2}{*}{$\begin{array}{c}\text { Concentration } \\
\left(\mu L^{-1}\right)\end{array}$} & \multicolumn{3}{|c|}{ N-TA (mg L-1) } & \multicolumn{3}{|c|}{$\mathrm{N}-\mathrm{NH}_{3}\left(\mathrm{mg} \mathrm{L}^{-1}\right)$} \\
\hline & & $6 \mathrm{~h}$ & $12 \mathrm{~h}$ & $24 \mathrm{~h}$ & $6 \mathrm{~h}$ & $12 \mathrm{~h}$ & $24 \mathrm{~h}$ \\
\hline Control & 0 & $0.73(0.25-1.28)^{\mathrm{ab}}$ & $0.50(0.49-0.50)^{a}$ & $1.20(0.30-1.90)^{b}$ & $0.12(0.04-0.16)^{\mathrm{ab}}$ & $0.07(0.07)^{\mathrm{a}}$ & $0.13(0.06-0.23)^{b}$ \\
\hline \multirow{3}{*}{ Clove oil } & 2.5 & $0.27(0.00-0.41)^{\mathrm{a}}$ & $0.00(0.00)^{b}$ & $0.00(0.00)^{b}$ & $0.05(0.00-0.08)^{a}$ & $0.00(0.00)^{b}$ & $0.00(0.00)^{b}$ \\
\hline & 5.0 & $0.22(0.00-0.45)^{\mathrm{a}}$ & $0.00(0.00)^{b}$ & $0.00(0.00)^{b}$ & $0.03(0.00-0.08)^{a}$ & $0.00(0.00)^{b}$ & $0.00(0.00)^{b}$ \\
\hline & 7.5 & $0.00(0.00-0.13)$ & $0.00(0.00)$ & $0.00(0.00)$ & $0.00(0.00-0.02)$ & $0.00(0.00)$ & $0.00(0.00)$ \\
\hline \multirow{3}{*}{ Mint oil } & 20.0 & $0.10(0.09-0.10)^{\mathrm{ab}}$ & $0.22(0.18-039)^{a}$ & $0.00(0.00)^{b}$ & $0.01(0.01)^{a}$ & $0.0190 .01-0.03)^{\mathrm{a}}$ & $0.00(0.00)^{a}$ \\
\hline & 25.0 & $0.21(0.10-0.45)^{\mathrm{a}}$ & $0.21(0.18-0.43)^{\mathrm{a}}$ & $0.00(0.00)^{b}$ & $0.03(0.01-0.08)^{a}$ & $0.02(0.01-0.04)^{a}$ & $0.00(0.00)^{b}$ \\
\hline & 30.0 & $0.24(0.10-0.65)^{\mathrm{a}}$ & $0.14(0.03-0.20)^{\mathrm{a}}$ & $0.00(0.00)^{b}$ & $0.02(0.01-0.08)^{a}$ & $0.01(0.00-0.02)^{b}$ & $0.00(0.00)^{b}$ \\
\hline \multirow{3}{*}{ Camphor oil } & 100.0 & $0.00(0.00)^{a}$ & $0.11(0.01-0.23)^{\mathrm{b}}$ & $0.11(0.00-0.32)^{b}$ & $0.00(0.00)$ & $0.01(0.00-0.03)$ & $0.01(0.00-0.03)$ \\
\hline & 120.0 & $0.00(0.00)^{a}$ & $0.20(0.01-0.34)^{b}$ & $0.20(0.10-0.23)^{b}$ & $0.00(0.00)^{a}$ & $0.02(0.01-0.03)^{b}$ & $0.0290 .01-0.02)^{b}$ \\
\hline & 140.0 & $0.00(0.00)^{a}$ & $0.18(0.07-0.32)^{\mathrm{b}}$ & $0.00(0.00)^{a}$ & $0.00(0.00)^{a}$ & $0.02(0.00-0.04)^{b}$ & $0.00(0.00)^{a}$ \\
\hline
\end{tabular}

Note: Letters indicate statistical difference $(p<0.05)$ among tested confinement periods (horizontal). There were no statistical differences ( $>0.05)$ among treatments in the same confinement period (vertical) $(p>0.05)$

Table 3: Median (min and max) values of nitrogen in the form of total ammonium $\left(\mathrm{N}-\mathrm{TA}=\mathrm{NH}_{3}+\mathrm{NH}_{4}^{+}\right)$and non-ionized ammonia $\left(\mathrm{N}-\mathrm{NH}{ }_{3}\right)$ concentrations after different periods of Amphiprion ocellaris confinement using clove, mint and camphor oils as anesthetic and a control group.

presented statistical differences separately $(\mathrm{p}>0.05)$. After, these data were analyzed pooling all of the experimentation periods, and showed some significant differences caused by the anesthetics tested. As seen in Figure 1, the use of anesthetics caused DO concentrations in transport water to decrease by at least $10 \%$, reaching $16.71 \mathrm{mg} \mathrm{L}^{-1}$ (measured in the camphor oil treatment). The lowest median value, $11.88 \mathrm{mg} \mathrm{L}^{-1}$, was recorded in the clove oil treatment; this value was $56 \%$ higher in the control, reaching $18.57 \mathrm{mg} \mathrm{L}^{-1}$. The treatments with anesthetics featured greater variability in $\mathrm{pH}$ values (which ranged between 6.8 and 8.0) than the control (from 7.24 to 7.84). However, the greatest difference was observed in the concentrations of N-TA and N-NH. In this case, the medians measured for the control $(0.61$ and $0.08 \mathrm{mg} / \mathrm{l}$ of N-TA and $\mathrm{N}-\mathrm{NH}_{3}$, respectively) were significantly higher than those measured for treatments with clove (both medians were 0.00 ), mint (medians of 0.09 and 0.01 ) and camphor (medians of 0.02 and 0.00 ) oils.

\section{Effects of different fish densities on water quality during simulated confinement conditions}

Increasing the density of fish tended to increase the final measured concentrations of $\mathrm{CO}_{2}$ and $\mathrm{DO}$ in practically all of the treatments including the control (Table 2). There was an opposite trend for $\mathrm{pH}$ : the values decreased with greater densities. The largest differences in median $\mathrm{pH}$ were measured in the control (0.27), while these differences ranged between 0.11 and 0.18 for the other treatments. Concentrations of N-TA and N-NH measured in the control and in the treatments containing clove and camphor oils showed a significant increase beyond the density of 10 fish $\mathrm{L}^{-1}$. When using mint oil, such increase

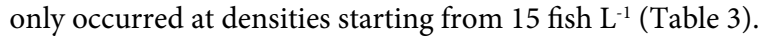

\section{Pooled analysis of data obtained during the simulated confinement in different animal densities}

The final DO concentrations recorded in the control were 29 to $42 \%$ higher than those measured in treatments containing anesthetics. In absolute terms, while the median DO in the control was $16.50 \mathrm{mg}$ $\mathrm{L}^{-1}$, the concentration for treatment containing mint oil was $11.65 \mathrm{mg}$ $\mathrm{L}^{-1}$ (Figure 2). The $\mathrm{CO}_{2}$ concentrations of the control and camphor oil treatments were $10 \mathrm{mg} \mathrm{L}^{-1}$, which is higher than the values in clove $(8.0$ $\left.\mathrm{mg} \mathrm{L}^{-1}\right)$ and mint $\left(8.5 \mathrm{mg} \mathrm{L}^{-1}\right)$ oils treatments.

The concentration (median) of N-TA in the control was $3.23 \mathrm{mg} \mathrm{L}^{-1}$, which was significantly higher than those observed in the treatments containing anesthetic oils. A similar pattern was observed for $\mathrm{N}-\mathrm{NH}_{3}$. The $\mathrm{N}-\mathrm{NH}_{3}$ concentration was $41 \%, 140 \%$ and $200 \%$ higher in the control (median $0.24 \mathrm{mg} \mathrm{L}^{-1}$ ) than the median concentrations obtained in treatments containing clove, mint and camphor oils, respectively. The $\mathrm{pH}$ results can be split into two groups: one including the control (median 7.03) and mint oil (median 7.00) and another group with 
Citation: Ostrensky A, Dal Pont G, Castilho-Westphal GG, Pedrazzani AS (2016) Use of Clove, Mint and Camphor Essential Oils on Confinement of Clown Anemonefish Amphiprion ocellaris (Cuvier 1830): Anesthetic Effects and Influence on Water Quality. J Aquac Res Development 7 : 457. doi: $10.4172 / 2155-9546.1000457$
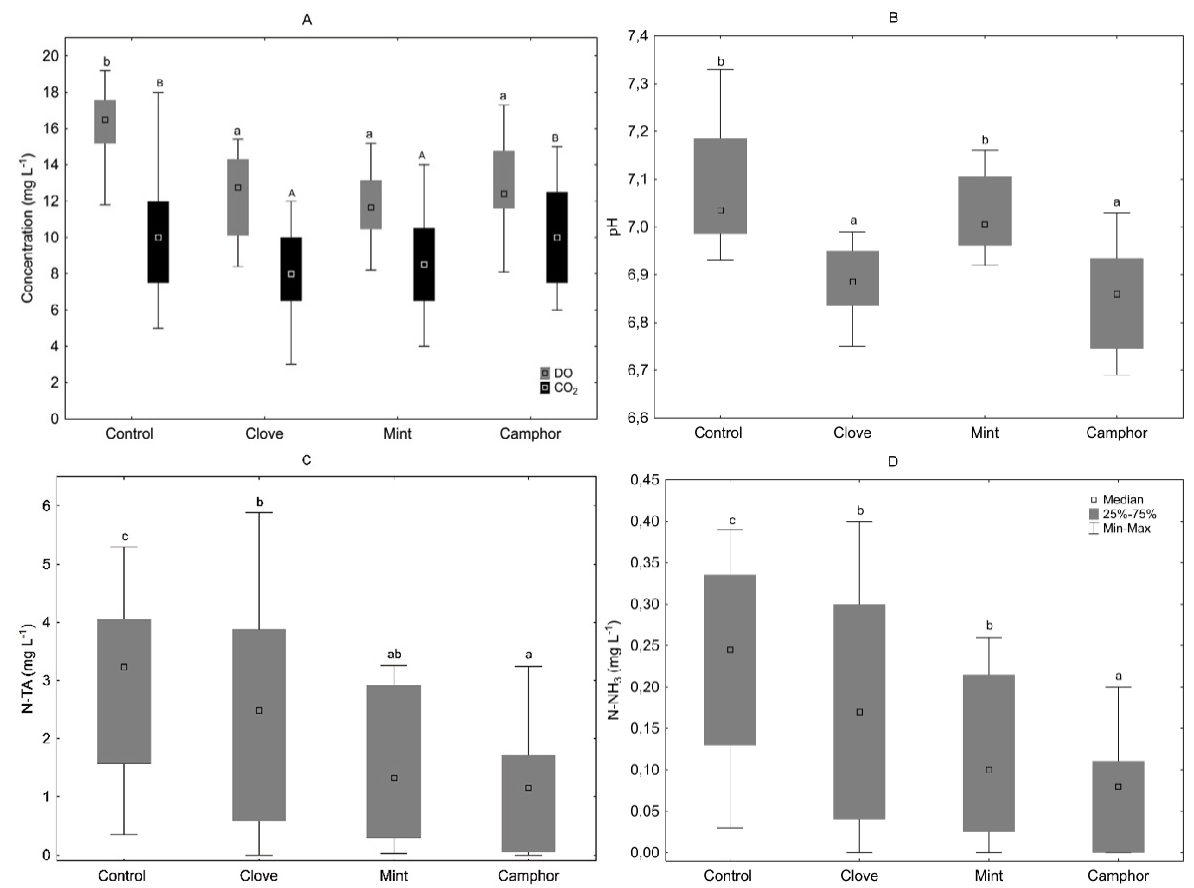

Figure 2: (A) Range of concentrations of dissolved oxygen (DO) and carbon dioxide $\left(\mathrm{CO}_{2}\right)$, (B) nitrogen in the form of total ammonium ( $\left.\mathrm{N}-\mathrm{TA}=\mathrm{NH}+\mathrm{NH}+\right)$ and nonionized ammonia $\left(\mathrm{N}^{-\mathrm{NH}_{3}}\right.$ ) and $(\mathrm{C}) \mathrm{pH}$ in transport water using clove, mint and camphor oils or no anesthetic (control). Different letters indicate significant differences among treatments $(\mathrm{p}<0.05)$.

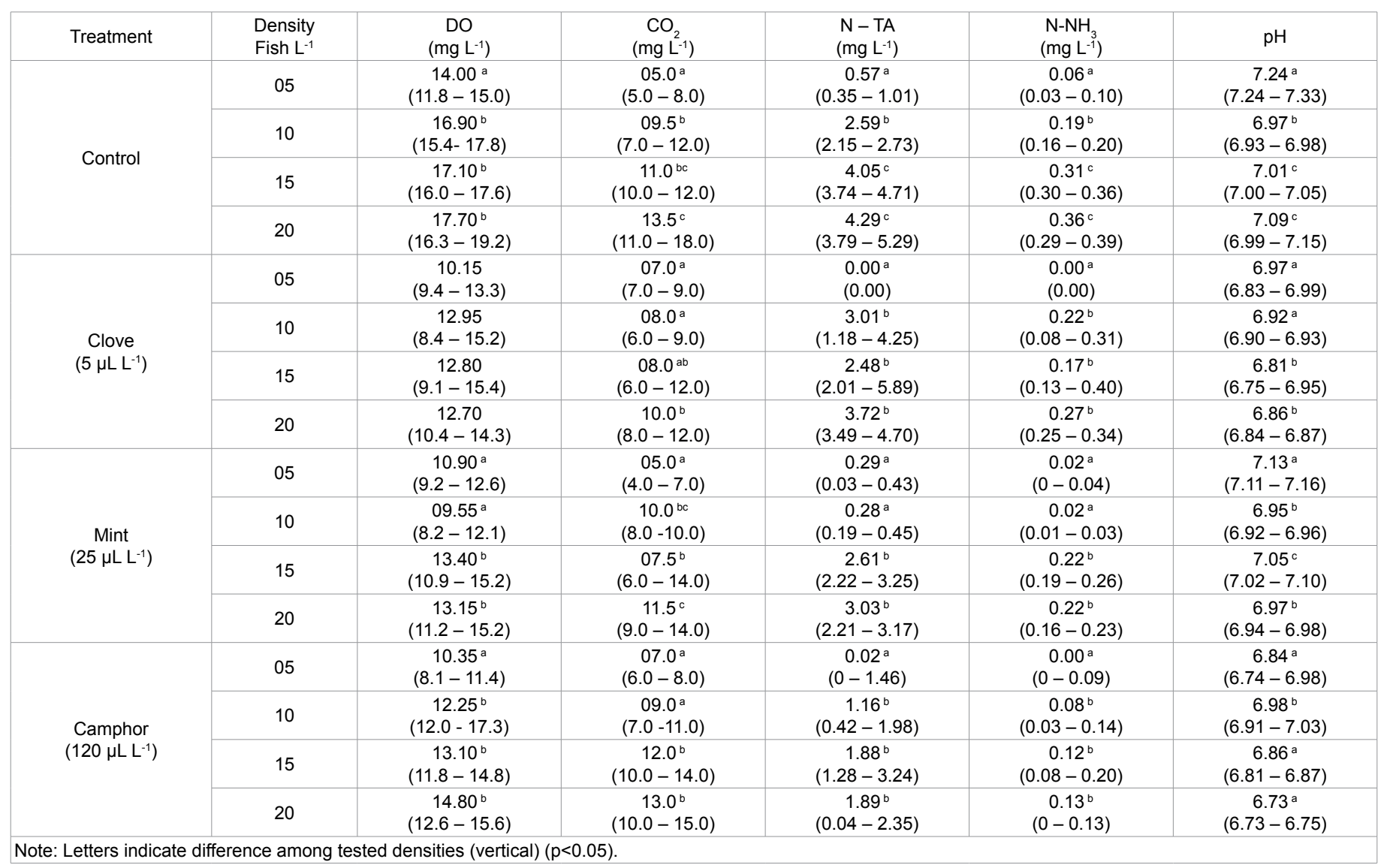

Table 4: Concentrations (median, min. and max.) of dissolved oxygen (DO), dissolved carbon dioxide $\left(\mathrm{CO}_{2}\right)$, total ammonium $(\mathrm{N}-\mathrm{TA})$ and non-ionized ammonia $\left(\mathrm{N}-\mathrm{NH}_{3}\right)$ and $\mathrm{pH}$ of water at $24 \mathrm{~h}$ after confinement using different densities of Amphiprion ocellaris combined with clove, mint and camphor oils or no anesthetic (control). 
Citation: Ostrensky A, Dal Pont G, Castilho-Westphal GG, Pedrazzani AS (2016) Use of Clove, Mint and Camphor Essential Oils on Confinement of Clown Anemonefish Amphiprion ocellaris (Cuvier 1830): Anesthetic Effects and Influence on Water Quality. J Aquac Res Development 7 : 457. doi: 10.4172/2155-9546.1000457

Page 6 of 7

lower values including the treatments with clove and camphor oils (medians of 6.88 and 6.86 , respectively) (Table 4 ).

\section{Discussion}

Establishing the concentration of a particular anesthetic to be used during the transport of reef fish is a very important and difficult task. If the anesthesia is too superficial, its effects can be null. However, if the anesthesia is too deep and causes a total loss of balance, the animals may sink and overlap at the bottom of the container, what, according to Coyle, Durborow [11], could lead to suffocation at high fish densities. Death can also occur due to poisoning effect caused by long exposure to the anesthetic itself. The substance's toxicity is associated with the duration of exposure, and its margin of safety decreases as the period of confinement increases [13,21]. Advanced stages of anesthesia involve reduced respiratory rate, leading to a reduction in blood $\mathrm{O}_{2}$ levels and a concomitant increase of $\mathrm{CO}_{2}$ levels, causing hypoxia [22]. In most cases, maintaining stage IV anesthesia for long periods without gill irrigation can result in death [23]. A combination of these factors could be responsible for the mortality that occurred in this study when using the highest concentrations of anesthetics.

Thus, among the tested concentrations, the intermediate ones (5, 25 and $120 \mu \mathrm{L} \mathrm{L}^{-1}$ of clove, mint and camphor oils, respectively) are the most appropriate for use in confinement for transportation of $A$. ocellaris. Although these concentrations induced stage III anesthesia (total loss of balance) during the first hours of transportation, they presented no deleterious effects to the fish. At these concentrations, the animals remained in stage II anesthesia (desirable) for most of the confinement transport period. In other words, the fish were subjected to a relatively mild degree of anesthesia that was still sufficient to safely mitigate the effects of adverse transport conditions.

These results indicate a clear influence of the duration of confinement transport on deterioration of water quality. In this regard, there were advantages and disadvantages of using anesthetics. The major advantage concerns the tendency to keep ammonia concentrations at low and safety levels over time. In the absence of anesthetics, animals maintained their normal metabolism and excreted more ammonia into the water. Because $\mathrm{pH}$ remained at proportionately higher in control compared to the treatments, especially clove and camphor oils, the concentrations of gaseous ammonia were significantly higher in the control. Because gaseous ammonia is known to be toxic to both fresh and saltwater fish [24,25] and other aquatic organisms [26], the use of anesthetics can potentially reduce the risk of animal death due accumulating toxic concentrations of nitrogenous wastes during confinement transport. In the control, $\mathrm{N}-\mathrm{NH}_{3}$ concentrations were recorded above $0.05 \mathrm{mg} \mathrm{L}^{-1}$, which is considered the acceptable limit for marine fish [27], thus supporting this claim.

One disadvantage is a tendency for greater variability on $\mathrm{pH}$ range during the use of anesthetics. However, the $\mathrm{pH}$ gradient observed in the present study seems to have been insufficient to cause death or harm to animals. According to Chow, Chen [28], A. ocellaris can withstand $\mathrm{pH}$ up to 6.3 under transport conditions, which is below the minimum value measured for all tested treatments. Mint oil allowed 10 fish $\mathrm{L}^{-1}$ to be transported without deleterious changes in water-quality parameters. In treatments containing clove and camphor oils, N-TA and $\mathrm{N}-\mathrm{NH}_{3}$ concentrations increased at this same density, indicating the lower efficacy of these oils at maintaining water quality at high densities. As expected, $\mathrm{CO}_{2}$ increased and $\mathrm{pH}$ consequently decreased at higher densities. However, there was also an increase in DO concentrations in all treatments over the duration of the experiment.
According to Pramod, Sajeevan [12], elevated $\mathrm{CO}_{2}$ concentrations reduce the capacity of hemoglobin to transport oxygen. Upon placing fish into an anesthetic solution, large amounts of mucus are secreted into the water and can accumulate in gills, thereby impairing gas exchange and consequently oxygen uptake. This impairment in the mechanism of gas exchange was also reported by Chow, Chen [28] and Pandit and Ghosh [29]. Studies involving the use of anesthetics during transport have also reported decreased oxygen uptake by guppy Poecilia reticulata [30], platy Xiphophorus maculatus [31] and angelfish [16]. The DO concentrations measured after $6 \mathrm{~h}, 12 \mathrm{~h}$ and $24 \mathrm{~h}$ were higher than the baseline in all tested treatments. This ideal confinement scenario is probably an association result from irrelevant oxygen consumption by fish under anesthetic influence and a high diffusion rate from pure oxygen atmosphere, created prior of the experimental beginning, to the water.

\section{Conclusion}

The use of essential oils for anesthetic purpose can be suggested as a viable way to reduce deleterious effects of confinement during transport of $A$. ocellaris. The results demonstrated the efficacy to use of mint oil $\left(25 \mu \mathrm{L} \mathrm{L}^{-1}\right)$ and to safely transport this species at density of 10 fish $\mathrm{L}^{-1}$. Clove $\left(5 \mu \mathrm{L} \mathrm{L}^{-1}\right)$ and camphor $\left(120 \mu \mathrm{L} \mathrm{L}^{-1}\right)$ oils could also be used at lower densities ( $5 \mathrm{fish} \mathrm{L}^{-1}$ ) to sedate fish during $24 \mathrm{~h}$ of confinement. It is also recommended the evaluation of the essential oils use as anesthetic substances associated with buffering substances and ammonia removers during $A$. ocellaris confinement and transportation.

\section{Acknowledgments}

We thank the Coordination for Improvement of Higher Education Personne (Coordenação de Aperfeiçoamento de Pessoal de Nível Superior - CAPES) fo a doctoral fellowship and the National Council for Scientific and Technological Development (Conselho Nacional de Desenvolvimento Científico e Tecnológico $\mathrm{CNPq}$ ) for providing a research productivity grant.

\section{References}

1. Bartley D (2000) Responsible ornamental fisheries, Food and Agriculture Organization of the U. N FAO Aquaculture Newsletter: Rome/ltaly.

2. Bruckner AW (2005) The importance of the marine ornamental reef fish trade in the wider Caribbean. Journal of Tropical Biology 53: 127-138.

3. Pomeroy RS, Parks JE, Balboa CM (2006) Farming the reef: is aquaculture a solution for reducing fishing pressure on coral reefs? Marine Policy 30: 111130

4. Green E (2008) International trade in marine aquarium species: Using the global marine aquarium database in marine ornamental species, Blackwell Publishing Company, 29-48.

5. UNEP (2008) United Nations Environment Programme. Consultation Process on Monitoring of International Trade in Ornamental Fish World Conservation Monitoring Centre - European Commission Directorate General E - Environment ENV.E.2. - Development and Environment: Cambridge, UK.

6. Leitritz E (1969) Fish Bulletin: Trout and salmon culture (Hatchery methods) D.o.F.a. Game, (Ed). State of California: California/USA.

7. Cole B, Tamaru CS, Bailey R, Brown C, Ako H (1999) Shipping practices in the ornamental fish industry. Center for Tropical and Subtropical Aquaculture.

8. Lin M, Wang Q, Xia Y, Murphy BR, Li Z, et al. (2012) Effects of two anesthetics on survival of juvenile culter mongolicus during a simulated transport experiment. North American Journal of Aquaculture 74: 541-546.

9. Lim LC, Dhert P, Sorgeloos $P$ (2003) Recent developments and improvements in ornamental fish packaging systems for air transport. Aquaculture Research 34: 923-935.

10. Cooke SJ, Suski CD, Ostrand KG, Tufts BL, Wahl DH (2004) Behavioral and physiological assessment of low concentrations of clove oil anaesthetic for handling and transporting largemouth bass (Micropterus salmoides) Aquaculture 239: 509-529. 
Citation: Ostrensky A, Dal Pont G, Castilho-Westphal GG, Pedrazzani AS (2016) Use of Clove, Mint and Camphor Essential Oils on Confinement of Clown Anemonefish Amphiprion ocellaris (Cuvier 1830): Anesthetic Effects and Influence on Water Quality. J Aquac Res Development 7: 457. doi: 10.4172/2155-9546.1000457

11. Coyle SD, Durborow RM, Tidwell JH (2004) Anesthetics in Aquaculture. United States Department of Agriculture, Cooperative State Research, Education, and Extension Service. Southern Regional Aquaculture Center.

12. Pramod PK, Sajeevan TP, Ramachandran A, Thampy S, Pai SS (2010) Effects of two anesthetics on water quality during simulated transport of a tropical ornamental fish, The Indian tiger barb Puntius filamentosus. North American Journal of Aquaculture 72: 290-297.

13. Ross LG, Ross B (2009) The Nature of Anaesthesia, Sedation and Analgesia. In: Anaesthetic and sedative techniques for aquatic animals, Blackwell Publishing Ltd

14. Cho GK, Heath DD (2000) Comparison of tricaine methane sulphonate (MS222) and clove oil anaesthesia effects on the physiology of juvenile Chinook salmon Oncorhynchus tshawytscha (Walbaum). Aquaculture Research 31: 537-546.

15. Ghanawi J, Monzer S, Saoud IP (2013) Anaesthetic efficacy of clove oil, benzocaine, 2-phenoxyethanol and tricaine methanesulfonate in juvenile marbled spinefoot (Siganus rivulatus). Aquaculture Research 44: 359-366.

16. Chellapan A, Rajagopalsamy CBT, Jasmine GI (2013) Effect of clove oil and benzocaine on the respiratory metabolism of angel fish Pterophyllum scalare.

17. Pedrazzani AS, Ostrensky A (2016) The anaesthetic effect of camphor (Cinnamomum camphora), clove (Syzygium aromaticum) and mint (Mentha arvensis) essential oils on clown anemone fish, Amphiprion ocellaris (Cuvier 1830). Aquaculture Research 47: 769-776.

18. APHA (2005) Standard methods for the examination of water and wastewater in 4500-NH3 F. Phenate Method. American Public Health Association.

19. Ostrensky A, Marchiori MA, Poersch LH (1992) Toxicidade Aguda da Amônia no Processo Produtivo de Pós-Larvas de Penaeus paulensis Pérez-Farfante, 1967. Anais da Academia Brasileira de Ciências 64: 383-389.

20. APHA (2005) American Public Health Association - Standard methods for the examination of water and wastewater, $450^{\circ} \mathrm{C}$ - Titrimetric method for free carbon dioxide $\left(\mathrm{CO}_{2}\right)$
21. Ross LG, Ross B (2009) Transportation and anaesthesia. In: Anaesthetic and sedative techniques for aquatic animals, Blackwell Publishing Ltd.

22. Thomas P, Robertson L (1991) Plasma cortisol and glucose stress responses of red drum (Sciaenops ocellatus) to handling and shallow wate stressors and anesthesia with MS-222, Quinaldine sulfate and metomidate. Aquaculture 96: 69-86.

23. Ackerman PA, Morgan JD, Iwama GK (2013) Anaesthetics, in Guidelines on the care and use of fish in research, teaching and testing. CCAC (Canadian Council on Animal Care).

24. Smart GR (1978) Investigations of the toxic mechanisms of ammonia to fishgas exchange in rainbow trout (Salmo gairdneri) exposed to acutely letha concentrations. Journal of Fish Biology 12: 93-104.

25. Eddy FB (2005) Ammonia in estuaries and effects on fish. Journal of Fish Biology 67: 1495-1513.

26. Ostrensky A, Wasielesky W (1995) Acute toxicity of ammonia to various life stages of the São Paulo shrimp, Penaeus paulensis Pérez-Farfante, 1967. Aquaculture 132: 339-347.

27. Olivier K (2008) World trade in ornamental species. In: Marine ornamental species, Blackwell Publishing Company, New York.

28. Chow PS, Chen TW, Teo LH (1994) Physiological responses of the common clownfish, Amphiprion ocellaris (Cuvier), to factors related to packaging and long-distance transport by air. Aquaculture 127: 347-361.

29. Pandit DN, Ghosh TK (1999) Effect of an anaesthetic, benzocaine on the aquatic oxygen uptake in juveniles of facultative air-breathing fish, Heteropneustes fossilis (Bloch). Journal of Freshwater Biology 12: 3-4.

30. Teo LH, Chen TW (1993) A study of metabolic rates of Poecilia reticulata Peters under different conditions. Aquaculture Research 24: 109-117.

31. Guo FC, Teo LH, Chen TW (1995) Effects of anaesthetics on the water parameters in a simulated transport experiment of platy fish, Xiphophorus maculatus (Günther). Aquaculture Research 26: 265-271. 